\title{
Radioactive Air Emissions Program Notice of Construction, Rotary Mode Core-Sampling Truck and Exhauster
}

Date Published

May 1993 


\section{CONTENTS}

1.0 FACILITY INFORMATION . . . . . . . . . . . . . . 1

2.0 SOURCE INFORMATION ................... 1

2.1 LISTING OF SOURCE .................. 1

2.2 DESCRIPTION OF THE SOURCE ............... 2

2.2 .1 System Function/Area Exhausted . . . . . . . . . 2

2.2.2 Effluent System Layout .............. 2

2.2.3 Efficiency Values of Each Control Device for Removal $22_{2}$

2.2.4 Means and Frequency of Testing and Inspecting

Effluent Treatment Systern .......... 2

2.2.5 Operating Mode (Cont inuous or Batch) ........ 2

2.2.6 Chemical and Physical Forms of the Releases ....... 4

2.2.7 Stack Data ................ . . 4

2.3 DESCRIPTION OF THE EFFLUENT SAMPLING/MONITORING SYSTEM . . . 5

3.0 GENERAL INFORMATION ON SAMPLE ANALYSIS ............ 5

4.0 DEMONSTRATION OF COMPLIANCE _......... 5

4.1 METHODOLOGY USED TO DEMONSTRATE COMPLIANCE ........ 5

4.2 INPUT DATA USED-SOURCE TERM .............. 5

4.3 RESULTS OF THE METHOD . . . . . . . . . . . . . . 6

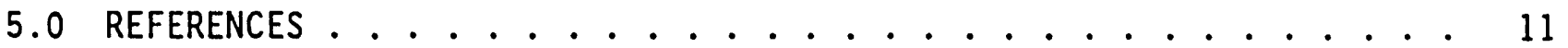

APPENDIXES:

A. PRELIMINARY TANK ORDER ................ . . . .

B. DISCUSSION OF BEST AVAILABLE RADIONUCLIDE CONTROL TECHNOLOGY :

\section{LIST OF FIGURES}

Figure $1 \ldots \ldots \ldots \ldots$

\section{LIST OF TABLES}

1 Average Rotary Mode Tank Emissions . . . . . . . . . . . 7

2 High Cs-137 Tank Emissions ................ 8

3 High $\mathrm{Sr}-90$ Tank Emissions ................. 9

4 offsite Dose .................... 10 


\section{ACRONYMS}

BARCT

DOH

EDE

EPA

HEPA

MEI

SST

Tri-Party

Agreement

VOC

WHC best available radionuclide control technology

State of Washington Department of Health

effective dose equivalent

U.S. Environmental Protection Agency

high-efficiency particulate air

maximally exposed individual

single-shell tank

Hanford Federal Facility Agreement and Consent Order

volatile organic compounds

Westinghouse Hanford Company 
$\mathrm{DOE} / \mathrm{RL}-93-40$

\section{RADIOACTIVE AIR EMISSIONS PROGRAM NOTICE OF CONSTRUCTION, ROTARY MODE CORE-SAMPLING TRUCK AND EXHAUSTER}

\subsection{FACILITY INFORMATION}

Efforts have been ongoing to obtain core samples from the contents of each of the Hanford Site's 149 single-shell tanks (SSTS). The SSTs contain various amounts ard combinations of liquid, sludge, and saltcake. Existing sampling equipment is unable to retrieve samples of hardened waste withir. established tank safety restrictions (particularly limits on temperature).

A new rotary mode core-samp?ing system has been designed to sample tanks containing hardened wastes. The prominent feature of this new system is the use of a nitrogen gas purge. The nitrogen gas purge will cool the drill bit and prevent cross contamination of different waste layers in the tank. The nitrogen gas purge will also allow more complete sample recovery, by clearing cuttings that might otherwise obstruct the sampler or drill bit. Nitrogen was chosen over other compressed gases for its inherent safety.

Many of the tanks to be sampled with the rotary mode core-sampling system are not actively ventilated, these tanks are operated at atmospheric pressure with passive (breather) high-efficiency particulate air (HEPA) filters.

Unless a ventilation system of the proper capacity is used, addition of the nitrogen purge gas to SSTs will cause the tanks to pressurize. Additionally, the use of the rotary mode core-sampling system will generate aerosols and dusts potentially containing radioactive particles in the tank vapor space.

Consequently, an exhauster will be required during operation of the rotary mode core-sampling system on SSTs to prevent tank pressurization and to control emissions. This exhauster will be required to be moved from tank farm to tank farm with the rotary mode core-sampling system.

\subsection{SOURCE INFORMATION}

\subsection{LISTING OF SOURCE}

The rotary mode core-sampling truck will be used on approximately 80 of the 149 SSTs in the 200 East and 200 West Areas of the Hanford Site. Each tank will have at least two complete cores taken, as part of the characterization efforts to support final disposal, waste tank safety programs, and the Hanford Federal Facility Agreement and Consent Order (also referred to as the Tri-Party Agreement) (Ecology et. al 1989). Both cores will be taken from each tank before moving the system to another tank, and movement of the exhauster and rotary mode core-sampling systems between tank farms will be limited. Several issues contribute to determining the order of tank sampling, and all tanks in a tank farm will not be sampled in succession. The first 
thirty tanks to be sampled using the rotary mode core-sampling system have been identified. Appendix A contains a preliminary list, which is subject to revision with changing priorities.

\subsection{DESCRIPTION OF THE SOURCE}

\subsubsection{System Function/Area Exhausted}

The space above the waste in the tank being rotary mode core-sampled will be exhausted. Further discussion of the operation of the rotary mode coresampling system is included in Section 2.2.5.

\subsubsection{Effluent System Layout}

The conceptual design of the exhauster system (i.e., control equipment, fan, and stack) is shown in Figure 1. The first part of the exhauster system consists of an in-riser prefilter, which can be backwashed into the tank to remove most of the larger particles and aerosols generated as a part of the rotary mode core-sampling. The second part consists of two testable HEPA filters, preceded by a prefilter in the HEPA filter housing. This second part is designed to remove the smaller particles, including particulate

radionuclides. The fan and stack complete the exhauster system.

\subsubsection{Efficiency Values of Each Control Device for Removal of Radioactivity}

Particulate radioactive emissions are of primary concern from the rotary mode core-sampling activities. The in-riser prefilter and prefilter/HEPA filter sections of the exhaust system are designed to remove both 7 arge and small particles from the air stream. The prefilter/HEPA section will be testable to ensure that $99.95 \%$ of the particles greater than $0.3 \mu \mathrm{m}$ will be removed from the air stream. A discussion of best available radionuclide control technology (BARCT) is included as Appendix B.

\subsubsection{Means and Frequency of Testing and Inspecting Effluent Treatment System}

The exhaust system will be inspected, each time the exhauster is moved, appraximately once a month during full scale operation. After every HEPA filter replacement, the efficiency will be tested.

\subsubsection{Operating Mode (Continuous or Batch)}

After the exhaust system and rotary mode core-sample system are connected to the tank to be sampled, and all required preoperational tests are complete, rotary mode core-sampling will progress. Preoperational tests include sampling of the vapor space for toxic air pollutants. An attempt 
DOE/RL-93-40

Figure 1 .

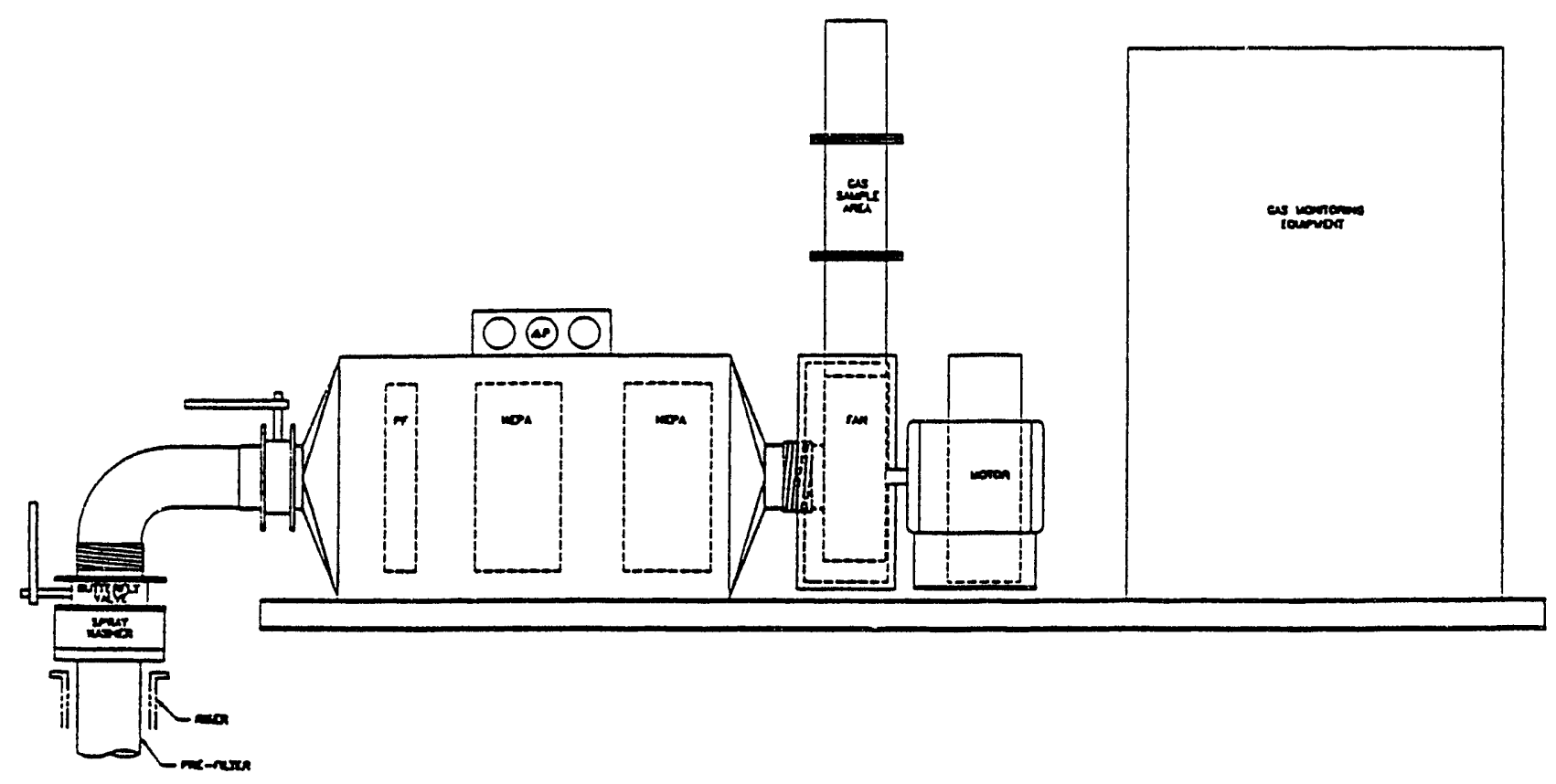


will be made to sample the waste using push mode. When instrumentation indicates that hard waste has been reached, the exhauster will be started and the drill bit will start rotating. Whenever the drill bit is rotating, njtrngen gas will be injected into the drill string at approximately 1.4 $\mathrm{m}^{3} / \mathrm{min}$ ( $50 \mathrm{ft}^{3} / \mathrm{min}$ ) (to a maximum of $2.8 \mathrm{~m}^{3} / \mathrm{min}\left[100 \mathrm{ft}^{3} / \mathrm{min}\right]$ ). Each $48-\mathrm{cm}$ (19-in.) segment requires drilling for 5 to $20 \mathrm{~min}$. While the sampler is being changed out after each segment, nitrogen will be injected into the drill string at approximately $0.03 \mathrm{~m}^{3} / \mathrm{min}\left(1 \mathrm{ft}^{3} / \mathrm{min}\right)$. This will maintain the hydrostatic head in the drill string (preventing waste from entering the space just sampled), and allows for pressurization and depressurization of the sample receiver, as necessary for sampler change out. The exhauster will be operated only while sampling activities are underway and will always be operating while nitrogen is injected at the higher flow rate. Actual sampling will consist of one or two 8-hour shifts per day.

Once a complete core has been obtained, the position of the rotary mode core-sampling truck will then be changed to allow a second core to be obtained. Upon completion of the second core, the exhauster and rotary mode core-sampling systems will be disconnected and moved to the next tank to be sampled. During sampler and exhauster connection and disconnection, as-lowas-reasonably-achievable principles will be followed including minimizing the time the riser is left open.

The fan will operate at approximately $5.6 \pm 1.4 \mathrm{~m}^{3} / \mathrm{min}$ $\left(200 \pm 50 \mathrm{ft}^{3} / \mathrm{min}\right)$. Approximately 15 tanks could be sampled each year. Each tank will take approximately I month to sample. This includes set-up and break-down time, in addition to the time required to move the rotary mode core-sample truck one time at each tank (to allow two complete cores to be taken).

\subsubsection{Chemical and Physical Forms of the Releases}

$\mathrm{Re}_{\mathrm{i}}$ eases as a result of rotary mode core-sampling activities will be primarily in particulate form. This is a result of rotating action of the drill bit which will increase particulate loading in the vapor space. Additionally, only a small percentage of the waste will be disturbed, therefore little, if any, non-particulate radionuclides will enter vapor space from the waste.

\subsubsection{Stack Da'ca}

The stack will be more than $3 \mathrm{~m}(10 \mathrm{ft})$ high with a 10.2-cm (4-in.)diameter duct. The average stack temperatures will be approximately $60^{\circ} \mathrm{C}$ $\left(140^{\circ} \mathrm{F}\right)$ and the exhaust rate will be approximately $5.6 \mathrm{~m} / \mathrm{min}\left(200 \mathrm{ft}^{3} / \mathrm{min}\right)$. Exit gas temperatures will vary with the temperature of the waste in the tank being sampled. Unit dose conversion tables were used in the preparation of this application (WHC 1991). Information previously provided to the Washington State Department of Health (DOH) provides the data used to model the source (e.g., Chi/Q and wind rose data). Information on the releases from the exhaust system are included in Section 4.2. 


\subsection{DESCRIPTION OF THE EFFLUENT SAMPLING/MONITORING SYSTEM}

The stack will be equipped with sampling equipment designed and operated in accordance with 40 CFR 61 , Subpart $H$, and all referenced requirements. Among other design criteria, sample probes will be designed to obtain representative samples, the location will be selected in accordance with referenced standards, and sample line length and bends will be minimized. The sampler for both beta and alpha radiation will operate continuously and will be calibrated and audited in accordance with procedures currently used in tank farms. Additionally, the stack will contain detectors for both volatile organic compounds (VOC) and ammonia.

\subsection{GENERAL INFORMATION ON SAMPLE ANALYSIS}

The stack sample media will be analyzed in accordance with existing procedures previously supplied to the DOH during audits.

\subsection{DEMONSTRATION OF COMPLIANCE}

\subsection{METHODOLOGY USED TO DEMONSTRATE COMPLIANCE}

Unit dose factors developed to support Facility Effluent Monitoring Plans were used to demonstrate compliance with WAC 246-247 and WAC 173-480. The factors are based on the computer model CAP-88, which is approved by the U.S. Environmental Protection Agency (EPA) to calculate the effective dose equivalent (EDE) to the maximally exposed individual (MEI). The MEI is located $16 \mathrm{~km}$ ( $10 \mathrm{mi}$ ) east of the 200 East Area of the Hanford Site. It was conservatively assumed that all emissions from the rotary mode core-sampling system would emanate from the 200 East Area, which results in a larger EDE.

\subsection{INPUT DATA USED-SOURCE TERM}

The exact contents of the SSTs are not known, which is why the rotary mode core-sampling system was designed to provide more information on tank contents. Unfortunately, that makes determining the source term of the tanks for the purposes of this application difficult. Several approaches were taken to try to bound the projected emissions from the rotary mode core-sampling activities. Those approaches involved the use of process knowledge, computer modeling, and parallel simulants tests.

As a result of tests conducted on waste simulants and computer maneling, an upper bound aerosol generation rate of $1 \mathrm{~kg}$ (conversion) per core was determined. This conservatively assumes that there is little open dome space, the waste is very dry, and there is extremely high air inleakage into the tank. 
Three estimates of tank waste radionuclide concentration were used to determine the upper bound release rates resulting from rotary mode coresampling: (1) the average of all tanks to be rotary mode core-sampled, (2) the tank with the highest concentration of Cs-137 (Tank 241-S-112), and (3) the tank with the highest concentration of Sr-90 (Tank 241-A-101). Each tank will have two cores sampled, and 15 tanks are assumed to be sampled each year. Table 1 includes the concentration of radionuclides in the "average tank" waste, the quantity of each isotope released to the emission control system for each core (i.e., unabated emission), the emissions from the exhaust system for each core (i.e., abated emissions), and the annual emissions (abated) from the average tank. A variety of isotopes is possible in the tank waste, but only those isotopes that would contribute at least 0.0001 percent of the unabated dose from the average tank are included in the table. Tables 2 and 3 provide the same information for the high cesium, and high strontium tanks, respectively, however all of the isotopes for the average tank are included. For the high cesium and high strontium tanks, this represents a greater percentage of the unabated dose.

\subsection{RESULTS OF THE METHOD}

Table 4 provides the offsite doses corresponding to the emissions shown in Tables 1 through 3 . The unit dose factors provided in the table were developed previously and can be found in WHC-EP-0498 (WHC 1991). It is conservatively assumed that all of the tanks sampled are located in the 200 East Area. Emissions from the 200 East Area result in larger offsite doses, because of the location of the MEI offsite $(16 \mathrm{~km}$ [10 mi]) east of 200 East, or $24 \mathrm{~km}$ [ $15 \mathrm{mi}]$ east of 200 West). It should be noted that the annual dose provided for both the high cesium and high strontium cases assume that all the tanks sampled have the same concentration. This provides an upper bound limit on the offsite dose.

All of the offsite doses provided are all less than $0.0006 \mathrm{mrem} / \mathrm{yr}$, to the offsite MEI. This value is highly conservative to account for uncertainties in the contents of the tank waste and the variability in particles generated as a result of the rotary mode core-sampling efforts. The dose resulting from all Hanford Site operations in 1991 was calculated at $0.007 \mathrm{mrem} / \mathrm{yr}$ (PNL 1992). The emissions as a result of rotary mode coresampling efforts, in conjunction with previous operations at the Hanford Site, will not result in a violation of the National Emission Standard of $10 \mathrm{mrem} / \mathrm{yr}$ (40 CFR 61). 
Table 1. Average Rotary Mode Tank Emissions.

\begin{tabular}{|c|c|c|c|c|}
\hline Isotope & $\begin{array}{c}\text { Concentration } \\
\text { in tank waste } \\
(\mathrm{C} i / g)\end{array}$ & $\begin{array}{l}\text { Released } \\
\text { to control } \\
\text { system, } \\
\text { each core } \\
\text { (unabated) } \\
\text { ( } \mathrm{C} i / \text { core) }\end{array}$ & $\begin{array}{l}\text { Emitted, } \\
\text { each core } \\
\text { (abated) } \\
\text { (Ci/core) }\end{array}$ & $\begin{array}{c}\text { Annual } \\
\text { emissions } \\
\text { (abated) } \\
(\mathrm{Ci} / \mathrm{yr})\end{array}$ \\
\hline $5 r-90^{\star}$ & 1.02 E-04 & $1.02 E-01$ & $5.10 E-05$ & $1.53 E-3$ \\
\hline $\operatorname{cs}-137^{\star}$ & $9.02 \mathrm{E}-05$ & 9.02 E-02 & $4.51 E-05$ & $1.35 E-03$ \\
\hline Am-241 & 7.61 E-08 & 7.61 E-05 & $3.80 E-08$ & $1.14 E-06$ \\
\hline $\mathrm{Pu}-239$ & $4.80 \quad E-08$ & $4.80 \quad E-05$ & $2.40 E-08$ & 7.2 E-07 \\
\hline$P u-240$ & $1.12 \mathrm{E}-08$ & $1.12 \mathrm{E}-05$ & $5.60 E-09$ & $1.68 E-07$ \\
\hline$P u-238$ & $2.91 E-09$ & $2.91 E-06$ & $1.45 E-09$ & $4.36 E-08$ \\
\hline $\mathrm{Pu}-241$ & $1.31 \quad E-07$ & $1.31 E-04$ & $6.55 E-08$ & $1.96 \quad E-06$ \\
\hline$U-238$ & $1.51 E-09$ & $1.51 E-06$ & $7.55 E-10$ & $2.26 \quad E-08$ \\
\hline$N p-237$ & $1.28 E-10$ & $1.28 E-07$ & $6.40 \mathrm{E}-11$ & $1.92 E-09$ \\
\hline $\mathrm{Cm}-244$ & $1.82 E-10$ & 1.82 E-07 & $9.10 E-11$ & $2.73 E-09$ \\
\hline $\mathrm{Am}-243$ & $3.97 E-11$ & 3.97 E-08 & $1.98 E-11$ & $5.95 E-10$ \\
\hline$U-235$ & $6.42 E-11$ & $6.42 E-08$ & $3.21^{\circ} \mathrm{E}-11$ & $9.63 \mathrm{E}-10$ \\
\hline $\mathrm{Ni}-63$ & $5.22 \quad E-07$ & $5.22 E-04$ & $2.61 E-07$ & $7.83 \quad E-06$ \\
\hline$C-14$ & 3.04 E-08 & 3.04 E-05 & $3.04 E-05$ & $9.12 \quad E-04$ \\
\hline Tc-99 & $6.33 \quad E-08$ & $6.33 E-05$ & $3.16 E-08$ & $9.49 \quad E-07$ \\
\hline $\mathrm{Cm}-242$ & $8.01 E-11$ & 8.01 E-08 & $4.00 \mathrm{E}-11$ & $1.20 \mathrm{E}-09$ \\
\hline$I-129$ & $9.64 \mathrm{E}-11$ & $9.64 \quad E-08$ & $9.64 E-08$ & $2.89 E-06$ \\
\hline$S n-126$ & $1.25 E-09$ & 1.25 E-06 & $6.25 E-10$ & $1.87 E-08$ \\
\hline
\end{tabular}

*Daughter products included in calculation. 
Table 2. High Cesium-137 Tank Emissions.

\begin{tabular}{|c|c|c|c|c|}
\hline Isotope & $\begin{array}{c}\text { Concentration } \\
\text { in tank waste } \\
(\mathrm{Ci} / \mathrm{g})\end{array}$ & $\begin{array}{l}\text { Released } \\
\text { to control } \\
\text { system, } \\
\text { each core } \\
\text { (unabated) } \\
\text { (Ci/core) }\end{array}$ & $\begin{array}{l}\text { Emitted, } \\
\text { each core } \\
\text { (abated) } \\
\text { (Ci/core) }\end{array}$ & $\begin{array}{c}\text { Annual } \\
\text { emissions } \\
\text { (abated) } \\
(\mathrm{Ci} / \mathrm{yr})\end{array}$ \\
\hline$S r-90^{\circ}$ & $1.89 E-04$ & $1.89 E-01$ & $9.45 E-05$ & $2.83 E-03$ \\
\hline $\mathrm{Cs}-137^{*}$ & $9.43 E-04$ & $9.43 \mathrm{E}-01$ & $4.71 E-04$ & $1.41 \mathrm{E}-02$ \\
\hline$A m-241$ & $1.89 E-07$ & $1.89 E-04$ & $9.45 E-08$ & $2.83 E-06$ \\
\hline$P u-239$ & $1.89 \mathrm{E}-10$ & $1.89 E-07$ & $9.45 E-11$ & $2.83 E-09$ \\
\hline $\mathrm{Pu}-240$ & $3.88 E-11$ & $3.88 E-08$ & $1.94 E-11$ & $5.82 E-10$ \\
\hline $\mathrm{Pu}-238$ & $5.66 \mathrm{E}-11$ & $5.66 \quad E-08$ & $2.83 E-11$ & $8.49 E-10$ \\
\hline $\mathrm{Pu}-241$ & $1.89 \mathrm{E}-10$ & $1.89 E-07$ & $9.45 E-11$ & $2.83 E-09$ \\
\hline$U-238$ & $3.77 \mathrm{E}-12$ & $3.77 E-09$ & $1.88 E-12$ & $5.65 E-11$ \\
\hline $\mathrm{Np}-237$ & $7.54 \quad E-10$ & $7.54 \quad E-07$ & $3.77 E-10$ & $1.13 \mathrm{E}-08$ \\
\hline $\mathrm{Cm}-244$ & $9.43 E-10$ & $9.43 E-07$ & $4.71 E-10$ & $1.41 \quad E-08$ \\
\hline$A m-243$ & $1.70 \mathrm{E}-10$ & $1.70 \quad E-07$ & $8.50 \mathrm{E}-11$ & $2.55 E-09$ \\
\hline$U-235$ & $1.32 \mathrm{E}-13$ & $1.32 E-10$ & $6.60 \mathrm{E}-14$ & $1.98 E-12$ \\
\hline $\mathrm{Ni}-63$ & $5.28 E-07$ & $5.28 E-04$ & 2.64 E-07 & 7.92 E-06 \\
\hline$C-14$ & $1.89 \quad E-07$ & $1.89 E-04$ & $1.89 \mathrm{E}-04$ & $5.67 E-03$ \\
\hline Tc-99 & 3.77 E-07 & $3.77 E-04$ & $1.88 \quad E-07$ & $5.65 E-06$ \\
\hline $\mathrm{Cm}-242$ & $1.89 E-10$ & $1.89 E-07$ & $9.45 E-11$ & $2.83 E-09$ \\
\hline$I-129$ & $7.54 E-10$ & 7.54 E-07 & 7.54 E-07 & 2.26 E-05 \\
\hline$S n-126$ & $1.89 E-10$ & $1.89 \quad E-07$ & $9.45 E-11$ & $2.83 E-09$ \\
\hline
\end{tabular}

*Daughter products included in calculation.

'Assumes a11 12 tanks have the same concentration. 
Table 3. High Strontium-90 Tank Emissions.

\begin{tabular}{|c|c|c|c|c|}
\hline I sotope & $\begin{array}{c}\text { Concentration } \\
\text { in tank waste } \\
(\mathrm{Ci} / \mathrm{g})\end{array}$ & $\begin{array}{l}\text { Released } \\
\text { to control } \\
\text { system, } \\
\text { each core } \\
\text { (unabated) } \\
\text { (Ci/core) }\end{array}$ & $\begin{array}{l}\text { Emitted, } \\
\text { each core } \\
\text { (abated) } \\
\text { (Ci/core) }\end{array}$ & $\begin{array}{l}\text { Annual } \\
\text { emissions } \\
\text { (abated) } \\
\text { (Ci/yr) }\end{array}$ \\
\hline $5 r-90^{*}$ & $3.78 E-04$ & $3.78 \mathrm{E}-01$ & $1.89 E-04$ & $5.67 E-03$ \\
\hline$C s-137^{*}$ & $0.00 E+00$ & $0.00 E+00$ & $0.00 E+00$ & $0.00 E+00$ \\
\hline$A m-241$ & $1.26 E-07$ & $1.26 E-04$ & $6.30 \quad E-08$ & $1.89 E-06$ \\
\hline$P u-239$ & $2.52 E-07$ & $2.52 E-04$ & $1.26 \quad E-07$ & $3.78 E-06$ \\
\hline$P u-240$ & $7.56 \quad E-08$ & 7.56 E-05 & 3.78 E-08 & $1.13 E-06$ \\
\hline $\mathrm{Pu}-238$ & $1.01 \quad E-08$ & $1.01 E-05$ & $5.05 E-09$ & 1.51 E-07 \\
\hline $\mathrm{Pu}-241$ & $7.56 \quad E-07$ & 7.56 E-04 & $3.78 \quad E-07$ & $1.13 E-05$ \\
\hline$U-238$ & $8.82 E-10$ & $8.82 \quad E-07$ & $4.41 E-10$ & 1.32 E-08 \\
\hline $\mathrm{Np}-237$ & $5.04 E-13$ & $5.04 E-10$ & $2.52 E-13$ & $7.56 \quad E-12$ \\
\hline $\mathrm{Cm}-244$ & $0.00 E+00$ & $0.00 E+00$ & $0.00 E+00$ & $0.00 E+00$ \\
\hline$A m-243$ & $3.78 \mathrm{E}-11$ & $3.78 E-08$ & $1.89 E-11$ & $5.67 \mathrm{E}-10$ \\
\hline$U-235$ & $3.78 E-11$ & $3.78 E-08$ & $1.89 \mathrm{E}-11$ & $5.67 \mathrm{E}-10$ \\
\hline $\mathrm{Ni}-63$ & $5.04 \mathrm{E}-06$ & $5.04 E-03$ & $2.52 E-06$ & $7.56 \mathrm{E}-05$ \\
\hline$C-14$ & $0.00 E+00$ & $0.00 E+00$ & $0.00 E+00$ & $0.00 E+00$ \\
\hline Tc-99 & $0.00 E+00$ & $0.00 E+00$ & $0.00 E+00$ & $0.00 E+00$ \\
\hline $\mathrm{Cm}-242$ & $1.01 E-10$ & $1.01 E-07$ & $5.05 E-11$ & $1.51 E-09$ \\
\hline$I-129$ & $0.00 E+00$ & $0.00 E+00$ & $0.00 E+00$ & $0.00 E+00$ \\
\hline$S n-126$ & $3.78 E-09$ & $3.78 E-06$ & $1.89 E-09$ & $5.67 E-08$ \\
\hline
\end{tabular}

*Daughter products included in calculation.

Assumes all 12 tanks have the same concentration. 
Table 4. Offsite Dose.

\begin{tabular}{|c|c|c|c|c|}
\hline Isotope & $\begin{array}{l}\text { Unit dose } \\
\text { factor, } \\
200 \text { East } \\
\text { (mrem/Ci) }\end{array}$ & $\begin{array}{l}\text { Annual dose, } \\
\text { average tank } \\
\text { (mrem/yr) }\end{array}$ & $\begin{array}{c}\text { Annual dose, } \\
\text { high Cs-137 tank } \\
\text { (mrem/yr) }\end{array}$ & $\begin{array}{l}\text { Annual dose, } \\
\text { high Sr-90 tank } \\
\text { (mrem/yr) }\end{array}$ \\
\hline$S r-90$ & $4.4 E-02$ & $6.70 E-05$ & $1.24 E-04$ & $2.48 E-04$ \\
\hline$C s-137$ & $2.4 E-02$ & $3.23 E-05$ & $3.38 \quad E-04$ & $0.00 E+00$ \\
\hline Am-241 & $1.3 E+01$ & $1.50 E-05$ & $3.71 E-05$ & $2.48 E-05$ \\
\hline$P u-239$ & $8.7 E+00$ & 6.24 E-06 & $2.46 E-08$ & 3.28 E-0.5 \\
\hline$P u-240$ & $8.7 E+00$ & 1.45 E-06 & 5.04 E-09 & 9.82 E-06 \\
\hline $\mathrm{Pu}-238$ & $8.0 E+00$ & 3.5 E-07 & $6.81 E-09$ & $1.22 E-06$ \\
\hline$P u-241$ & $1.4 E-01$ & 2.71 E-07 & $3.91 E-10$ & $1.56 E-06$ \\
\hline$U-238$ & $2.8 E+00$ & $6.46 E-08$ & $1.61 E-10$ & $E-76 \quad E-08$ \\
\hline $\mathrm{Np}-237$ & $1.2 E+01$ & $2.28 E-08$ & $1.35 E-07$ & $9.00 \mathrm{E}-11$ \\
\hline $\mathrm{Cm}-244$ & $6.9 E+00$ & $1.89 E-08$ & $9.82 E-08$ & $0.00 E+00$ \\
\hline$A m-243$ & $1.3 E+01$ & $7.8 E-09$ & 3.34 E-08 & 7.43 E-09 \\
\hline$U-235$ & $3.0 E+00$ & $2.85 E-09$ & $5.86 E-12$ & $1.68 E-09$ \\
\hline $\mathrm{Ni}-63$ & $2.0 E-04$ & $1.59 E-09$ & $1.61 \mathrm{E}-09$ & $1.54 E-08$ \\
\hline$C-14$ & $2.6 E-03$ & $2.39 E-06$ & $1.49 E-05$ & $0.00 E+00$ \\
\hline Tc-99 & $1.1 E-03$ & 1.03 E-09 & 6.16 E-09 & $0.00 E+00$ \\
\hline $\mathrm{Cm}-242$ & $4.2 E-01$ & 5.10 E-10 & $1.2 E-09$ & $6.43 E-10$ \\
\hline$I-129$ & $2.9 E-01$ & $8.42 E-07$ & $3.25 E-06$ & $0.00 E+00$ \\
\hline$S n-126$ & $8.6 E-03$ & $1.62 E-10$ & $2.45 E-11$ & $4.89 E-10$ \\
\hline Total & & 1.26 E-04 & $5.21 E-04$ & 3.19 E-04 \\
\hline
\end{tabular}




\subsection{REFERENCES}

ECology, EPA, and DOE, 1990, Hanford Federal Facility Agreement and Consent Order, 2 vols., as amended, State of Washington Departme.it nf Ecology, U.S. Environmental Protection Agency, and U.S. Department of' Energy, Richland, Washington.

PNL 1992, Hanford Site Environmental Report for Calendar Year 19.91, PNL 8148, Pacific Northwest Laboratory, Richland, Washington.

WHC, 1991, Unit Dose Calculation Methods and Summary of Facility Effluent Monitoring PIan Determinations, WHC-EP-0498, Westinghouse Hanford Company, Richland, Washington.

40 CFR 61, "National Emission Standards for Hazardous Air Pollutants (Ni.SHAP)" Code of Federal Regulations, as amended. 
DOE/RL-93-40

APPENDIX A

PRELIMINARY TANK ORDER

A-1 
DOE/RL-93-40

This page intentionally left blank.

A-2 


\section{APPENDIX A}

\section{PRELIMINARY TANK ORDER}

A preliminary list of the first 30 tanks to be sampled using the rotary mode core-sampling system is provided below. It should be noted that this list is subject to revision based on changing priorities at the Hanford Site.

Tank 241-BY-104

Tank 241-BY-110

Tank 241-BY-107

Tank 241-BY-105

Tank 241-BY-103

Tank 241-BY-112

Tank 241-U-106

Tank 241-TY-103

Tank 241-BY-106

Tank 241-BY-101

Tank 241-TY-101

Tank 241-U-107

Tank 241-S-110

Tank 241-TX-105

Tank 241-SX-103

\author{
Tank 241-SX-101 \\ Tank 241-BX-110 \\ Tank 241-SX-105 \\ Tank 241-AW-106 \\ Tank 241-SX-106 \\ Tank 241-S-112 \\ Tank 241-BX-111 \\ Tank 241-SX-104 \\ Tank 241-BY-111 \\ Tank 241-U-102 \\ Tank 241-A-101 \\ Tank 241-TX-118 \\ Tank 241-SX-102 \\ Tank 241-BY-108 \\ Tank 241-AX-101
}

The A, AW, AX, BX, and BY Tank Farmis are located in the 200 East Area while the S, SX, TX, TY, and U Tank Farms are located in the 200 West Area. 
DOE/RL-93-40

This page intentionally left blank. 
$\mathrm{DOE} / \mathrm{RL}-93-40$

\section{APPENDIX B}

DISCUSSION OF BEST AVAILABLE RADIONUCLIDE CONTROL TECHNOLOGY 
DOE/RL-93-40

This page intentionally left blank.

B-2 


\section{APPENDIX B \\ DISCUSSION OF BEST AVAILABLE RADIONUCLIDE CONTROL TECHNOLOGY}

A meeting was held with the State of Washington Departments of Health (DOH) and Ecology, the U.S. Department of Energy, Richland Operations Office, and Westinghouse Hanford Company on Or.tober 27, 1992, in which the Best Available Radionuclide Control Technology (BARCT) assessment for the rotary mode core-sampling truck exhauster was discussed. In that meeting, a "broadbrush" BARCT was presented, and preliminary approval was given by DOH for both the technology (high-efficiency particulate air [HEPA] filters) and the level of detail of the assessment.

A study on aerosol generation as a result of rotary mode core-sampling using simulated wastes showed that a large percentage (99.82) of the particles generated from rotary mode core-sampling are greater than $1.0 \mu \mathrm{m}$. The documentation for this simulation is currently being revised and will be provided when available. HEPA filters are tested to 99.95 percent efficiency for particles ranging from $0.1 \mu \mathrm{m}$ to $0.30 \mu \mathrm{m}$. The documentation for this study is currently being revised and will be provided to DOH when it is completed.

of the isotopes contributing substantially to the dose from the rotary mode core-sampling activities, only iodine and carbon are not expected to be in the form of particulates and would not be abated by particulate control technology. After installation of HEPA filters, I-129 and C-14 contribute less than 5 percent of the annual dose from the sampling activities (see Table 4 of the Notice of Construction to which this document has been appended). The percentage of unabated dose from I-129 and C-14 is even smaller, (i.e., approximately 0.0020 percent) for the high cesium tank.

It is proposed that the system described in this application be approved for BARCT for this exhauster. The in-riser prefilter and prefilter/HEPA filter sections of the exhaust system are designed to remove both large and small particles from the air stream. Using the in-riser prefiiter (which can be backwashed into the tank) to remove larger particles prevents the HEPA filters from becoming loaded and requiring to be changed frequently. This reduces worker dose and the amount of waste that must be disposed of as radioactive waste. HEPA filter systems have been used extensively at the Hanford Site and in other situations where very small particles must be controlled.

A DOH representative expressed interest in recirculation of the exhaust into the tank as a result of the October 27,1992 meeting. This is not a feasible option in this situation. The exhauster size will accommodate inleakage around cover blocks, breather filters, and adjoining tanks, and the nitrogen being injected into the tank. Recirculation would not reduce the inleakage substantially, and $5.6 \mathrm{~m}^{3} / \mathrm{min}\left(200 \mathrm{ft}^{3} / \mathrm{min}\right)$ would still need to be exhausted from the system. Consequently, recirculation would only result in an increase in the flow through the control equipment, potentially increasing the worker dose and the physical size of the equipment. The rotary mode coresampling system is a system that is required to be moved frequently, therefore any increase in size of the equipment increases the complexity of moving the 
equipment. The area available for equipment in some tank farms is limited, and limits exist on the weight of equipment, which can be placed on tanks. Therefore, recirculation is not feasible in this situation. 
DOE/RL-93-40

\section{DISTRIBUTION}

Number of copies

OFFSITE

1

State of Washington Department of Health Division of Radiation Protection

Air Emissions and Defense Waste Section Airdustrial Park Building 5 Olympia, WA 98504-0095

A. W. Conklin, Head

\section{ONSITE}

5

U.S. Department of Enerqy-

Richland Operations Office

J. M. Clark

A4-02

P. R. Hernandez

A4-02

E. M. Mattlin

S. D. Stites

A4-02

Public Reading Room

A5- 15

Al-65

1

Pacific Northwest Laboratory

Technical Library

$\mathrm{K} 1-11$

21

Westinghouse Hanford Company

B. A. Austin

B2-35

J. A. Bates

H6-22

F. 0. Grey

A2-24

D. B. Hagmann

S2-46

G. W. Jackson

H6-21

J. R. Kasper

R2-50

R. J. Landon

H6-22

J. J. Luke

P. J. Mackey

H6-25

M. J. Minette

B3-15

R. W. Oldham

S2-46

D. N. Price

H6-25

J. D. Robinson

R2-14

C. E. Sowa (3)

H5-09

W. F. Zuroff

H6-25

CES File/LB

R2-14

Document Processing and Control

H6-25

EDMC

L8-13

Information Release Administration

H6-08

A3-36 
DOE/RL-93-40

This page intentionally left blank. 

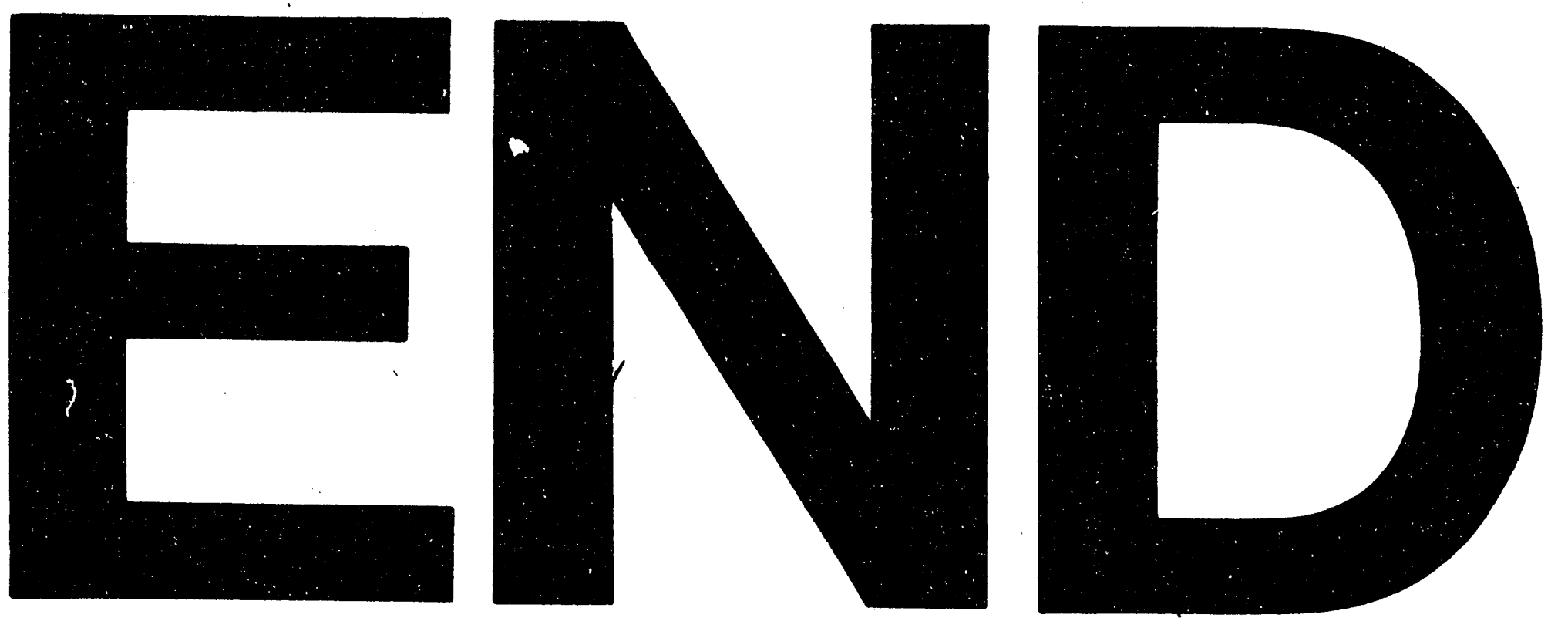

1
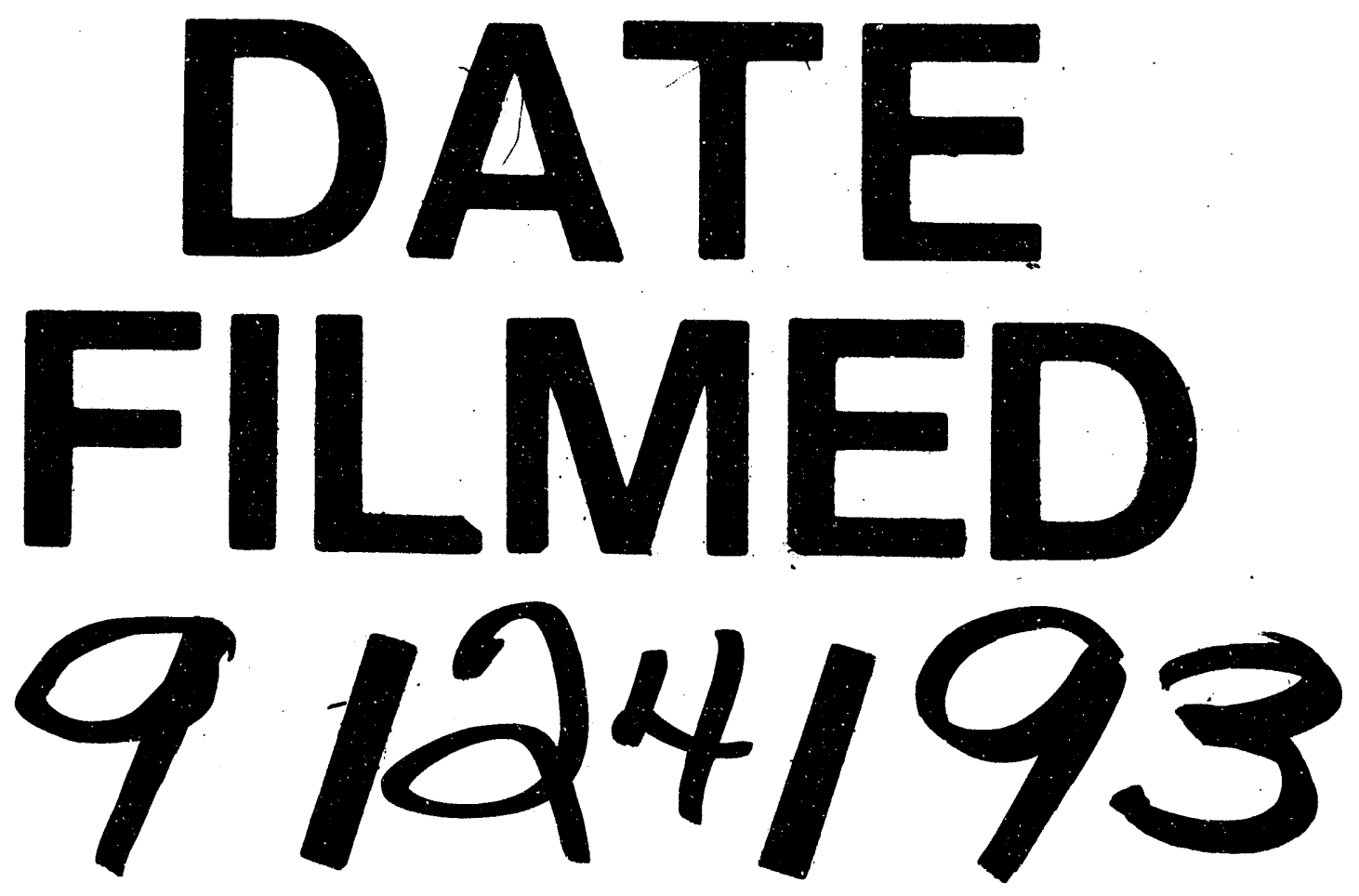
